Full-text Available Online at www.bioline.org.br/ja
J. Appl. Sci. Environ. Mgt. September, 2006

Vol. 10 (3) 141- 146

\title{
Biotoxic effects of the herbicides on growth, seed yield, and grain protein of greengram
}

\author{
KHAN, M S; CHAUDHRY, P; WANI, P A; ZAIDI, A
}

\author{
Department of Agricultural Microbiology, Faculty of Agricultural Sciences, Aligarh Muslim University, Aligarh 202002, India
}

\begin{abstract}
We studied the effects of atrazine, isoproturon, metribuzin and sulfosulfuron on plant vigour, nodulation, chlorophyll content, seed yield and protein content in seeds, in greengram inoculated with Bradyrhizobium $s p$. (vigna). The pre-emergence application of the four herbicides at $400 \mu \mathrm{g} \mathrm{kg}^{-1}$ of soil adversely affected the measured parameters. The average maximum increase of $10 \%$ in seed yield occurred at $200 \mu \mathrm{g} \mathrm{kg}^{-1}$ of sulfosulfuron, while atrazine at 200 and $400 \mu \mathrm{g} \mathrm{kg}^{-1}$ of soil decreased the seed yield by $25 \%$ and $40 \%$, respectively. The average maximum chlorophyll content of $1.2 \mathrm{mg} \mathrm{g}^{-1}$ was obtained at $200 \mu \mathrm{g} \mathrm{kg}^{-1}$ of sulfosulfuron which declined consistently for all herbicides and increasing dose rates. Sulfosulfuron at $200 \mu \mathrm{g} \mathrm{kg}^{-1}$ increased the number of nodules found per plant by $7 \%$ at 45 days after seeding the greengram. In contrast, the tested dose rates of atrazine, isoproturon and metribuzin significantly reduced the nodulation (nodule number and dry mass). The average maximum grain protein of $182 \mathrm{mg} \mathrm{g}^{-1}$ was obtained for sulfosulfuron at $400 \mu \mathrm{g} \mathrm{kg}^{-1}$, while minimum grain protein was obtained at $400 \mu \mathrm{g} \mathrm{kg}^{-1-}$ of isoproturon $\left(124 \mathrm{mg} \mathrm{g}^{-1}\right)$ and atrazine $\left(125 \mathrm{mg} \mathrm{g}^{-1}\right)$ application. Among the herbicides tested, atrazine and metribuzin showed a large degree of phytotoxicity to the crop, inhibiting its vegetative growth and was thus incompatible with greengram.@JASEM
\end{abstract}

The nitrogen fixing bacterium Bradyrhizobium sp. (vigna) forms a specific symbiosis with greengram [Vigna radiata $(\mathrm{L}$.$) wilczek] and is commonly applied$ to the seed or soil as microbial inoculant to ensure functional symbiosis in this crop. Further, during the production of greengram, broad and narrow leaved weeds appear which adversely affect the productivity of greengram. The herbicides are therefore, required to control weeds in order to augment the yield. There are reports that suggest that herbicides when applied indiscriminately had variable effects on legume production (Khan et al., 2004). Moreover, the effects of herbicides are affected by the type and rates of its application, health and stages of plant growth, and other environmental variables. When applied frequently, the herbicides are accumulated in to the soil and at elevated levels impair the metabolic activities resulting in reduced growth of rhizobia, legumes or both. For instance, the photosynthesis inhibiting herbicide (metribuzin) affects the Rhizobium sp. (Heinonen-Tanski et al., 1982), the plant (Rennie and Dubetz, 1984) and the legume Rhizobium symbiosis (Malik and Tesfai, 1985). Metribuzin and alachlor at recommended and five times more of recommended rates caused a significant reduction in nodulation, nitrogense activity and total $\mathrm{N}$ content in soybean (Malik and Tesfai, 1985). In a similar study, the recommended and double the rates of metribuzin inhibited growth, nodulation and $\mathrm{N}_{2}$ fixation in cowpea without adversely affecting the $\mathrm{N}$ uptake by the plant (Silva et al., 1998). Fluchloralin and pendimethalin when applied under field conditions significantly decreased nodulation on soybean inoculated with Bradyrhizobium japonicum (Bollich et al., 1985).On the contrary, Billore et al., (2001) observed a significant increase in the dry matter accumulation in soybean following pendimethalin application in a two year field trial. In a similar study, fluchloralin when applied at normal rates, showed a considerable increase in nodulation on root system of groundnuts while the same rate of benefin, dinitroamine and nitralin decreased nodule mass, nitrogenase activity, yield and total $\mathrm{N}$ content, under field and greenhouse conditions (Durgesha, 1994).

Geengram is an important grain legume crop of the world and is grown widely in the tropical countries. In India, greengram occupies an area of three millionhectare, accounting for $14 \%$ of total pulses area and $7 \%$ of total production (Singh et al., 2004). A relatively little information available on the effect of herbicides on greengram productivity formed the basis of this experiment. The present study evaluates the effects of commercial grades of atrazine, metribuzin, isoproturon and sulfosulfuron, on the Bradyrhizobium sp. (vigna) in pure culture and on vitality, nodulation, seed yield and grain protein of greengram, grown in clay pots.

\section{MATERIALS AND METHODS}

A total of 40 strains of Bradyrhizobium were isolated from nodules of greengram using standard methods (Holt et al., 1994). Strains of Bradyrhizobium were isolated using serial dilution plate technique on solid yeast extract mannitol (YEM) $\left(\mathrm{g} \mathrm{l}^{-1}\right.$ : mannitol 10; $\mathrm{K}_{2} \mathrm{HPO}_{4} \quad 0.5 ; \mathrm{MgSO}_{4} .7 \mathrm{H}_{2} \mathrm{O} \quad 0.2 ; \mathrm{NaCl} 0.1$; yeast extract 1.0; $\mathrm{CaCO}_{3} 2 ; \mathrm{pH} 7$ ) and were maintained on the same medium until use. The sensitivity/resistance of herbicides to Bradyrhizobial isolates was determined by plate dilution method. The herbicides used were: atrazine (gesaprim, e.c. 70\%, Om Krishi, 
Aligarh), isoproturon (arelon, e.c. 70\%, Singhl Pesticides, Mumbai), metribuzin (captain, e.c. 70\%, Singnal Pesticides, Mumbai) and Sulfosulfuron (maverick, e.c 95\%, Agricultural Chemicals Division, I. A. R. I., New Delhi). The herbicides were applied at $100-6400 \mu \mathrm{g} / \mathrm{ml}$, and were supplemented in sterilized YEM agar plates. The test organisms were grown in YEM broth for 3-5 days to a density of $\cong 10^{8}$ cells $\mathrm{ml}^{-1}$ and were spot inoculated onto the YEM agar plates and incubated at $30{ }^{\circ} \mathrm{C}$ for four days. The lowest concentration of each herbicide inhibiting rhizobial growth on YEM agar plates was defined as minimum inhibitory concentration (MIC) of the herbicides. The indole acetic acid (IAA) was quantitatively estimated by the method of Gordon and Weber (1951) and later modified by Brick et al., (1991). Rhizobial isolates were grown in Luria Bertani (LB) broth (g/l: tryptone 10; yeast extract 5 ; $\mathrm{NaCl} 10$ and $\mathrm{pH} 7.5$ ). A $100 \mathrm{ml}$ of LB broth amended with tryptophan $\left(50,75\right.$ and $100 \mu \mathrm{g} \mathrm{ml}^{-1}$ ) was inoculated with one $\mathrm{ml}$ culture $\left(\mathrm{x} 10^{8} \mathrm{cells} / \mathrm{ml}\right)$ and incubated for $24 \mathrm{~h}$ at $28{ }^{\circ} \mathrm{C}$ in an incubator shaker at $125 \mathrm{rpm}$. After $24 \mathrm{~h}$, five $\mathrm{mL}$ of each culture was centrifuged separately for $15 \mathrm{~min}$. and two $\mathrm{mL}$ of Salkowsky reagent $(2 \% 0.5 \mathrm{M} \mathrm{FeCl} 3$ in $35 \%$ perchloric acid) was added to two $\mathrm{mL}$ of supernatant and incubated at $28{ }^{\circ} \mathrm{C}$ under dark for $1 \mathrm{~h}$. The IAA was quantified by spectrophotometer $(\lambda 540 \mathrm{~nm})$ using IAA as standard. The experiment was repeated three times. The rhizobial strain (BR9) showing greater resistance to the tested herbicides and producing substantial amounts of IAA was selected for further plant inoculation studies. Bradyrhizobium sp. (vigna) was grown in YEM broth in flasks at $28{ }^{\circ} \mathrm{C}$ for four days to a cell density of $4 \times 10^{8}$ cells per ml. Seeds of greengram (cv. K-851) were surface sterilized $(70 \%$ ethanol, 3 min.; $3 \%$ sodium hypochlorite, $3 \mathrm{~min}$.), rinsed six times with sterile water and air-dried before being inoculated with Bradyrhizobium sp. (BR9) by dipping the seeds in the liquid culture medium for $1 \mathrm{~h}$ using $10 \%$ gum arabic as the sticker to apply approximately $10^{8}$ cells to each seed. Using soil incorporated applications of commercial formulations to moist soil $24 \mathrm{~h}$ before sowing the seeds in clay pots $(23 \times 20 \mathrm{~cm}$ diam. $)$, the effects of the four herbicides (atrazine, isoproturon, metribuzin and sulfosulfuron) were evaluated at 200 and $400 \mu \mathrm{g}$ a.i. $\mathrm{kg}^{-1}$ of soil. Some pots not treated with herbicides were sown with inoculated seeds and used as control treatments for comparison. Fertilizer at 15:40 mg kg-1 soil $\mathrm{N}$ as urea and $\mathrm{P}$ as diammonium phosphate was dissolved in distilled water and added to the surface of the soil at the time of sowing. Ten inoculated seeds were sown in each pot containing $6 \mathrm{~kg}$ non-sterilized sandy clay loam soils $\left(0.4 \%\right.$ organic carbon, $0.75 \mathrm{~g} \mathrm{~kg}^{-1} \mathrm{~N}, 16 \mathrm{mg} \mathrm{kg}$ ${ }^{1} \mathrm{P}, \mathrm{pH} 7.2$, and $0.44 \mathrm{ml} \mathrm{g}{ }^{-1}$ WHC) that had not been treated previously with the herbicides. Six pots were used for each treatment and were arranged in a complete randomized block design in a glass house. One week after emergence, the seedlings were thinned to four in each pot. The pots were hand weeded at regular intervals and watered with tap water daily and maintained at $25 \pm 2{ }^{\circ} \mathrm{C}$ and $60 \%$ r.h. For each treatment, all plants in three pots were uprooted 45 days after seeding (DAS), and the extent of nodulation was estimated by carefully washing the roots and detaching the nodules before counting, oven drying (at $80{ }^{\circ} \mathrm{C}$ ) and weighing them. The remaining three pots for each treatment were harvested 70 DAS and the length of plant parts (e.g., roots and shoots), seed yield and seed protein (Lowrey, 1951) were measured. The plants harvested 70 DAS were oven dried (at $80{ }^{\circ} \mathrm{C}$ ) to measure the total phytomass. The total chlorophyll content of the fresh foliage was determined at 45 DAS (Mechenny, 1941). The experiment was repeated for two consecutive years to ensure the reproducibility of the results. The data of two years trial were pooled together and subjected to statistical calculations using Statistical Package for Social Science and Duncan multiple range test (DMRT) was used to determine significant differences among means at 5\% level of probability.

\section{RESULTS AND DISCUSSION}

During the initial screening process, we isolated 40 bradyrhizobial strains from the nodules of greengram, grown at the Faculty of Agricultural Sciences, A. M.U., Aligarh. Out of 40 isolates, the strain BR9 was specifically chosen based on its relatively higher growth and was characterized morphologically and biochemically. The strain BR9 was gram negative, short rods and produced white transparent and mucoid colonies on YEM agar plates. The freshly grown culture showed positive tests for starch hydrolysis, catalase and citrate. The effect of the four herbicides atrazine, isoproturon, sulfosulfuron and metribuzin on strain BR9 was tested in solid YEM medium. The nodule bacteria differed considerably in their sensitivity towards herbicides on YEM agar plates and showed a greater variation in MIC values (Fig. 1). The MIC value of isolate BR9 ranged between 3200 (atrazine and isoproturon) and $6400 \mu \mathrm{g} \mathrm{ml}^{-1}$ (metribuzin and sulfosulfuron). It appeared that atrazine and isoproturon were the most damaging while metribuzin and sulfosulfuron the least. The results reported here are based on studies conducted on YEM agar plates. However, other research has shown that the effect of herbicides on the growth of rhizobia can be quite different depending upon the method used. For instance, Martensson (1992) obtained quite different results in liquid broth experiments without the addition of agar from those in agar based methods and was of the view that the 
presence of agar may influence the mode of action of the investigated compounds, probably due to the complex formation with the agar. However, the report suggests that the persistence of herbicides when applied in soil is influenced by its adsorption by the soil and many other factors including volatization, photodecomposition, leaching, and degradation by soil microorganisms (Cork and Krueger, 1991), resulting in the reduced availability of these chemicals leading from little to no effect on rhizobia.

Table 1. Effect of two dose rates of atrazine, isoproturn, metribuzin and sulfosulfuron on plant growth, nodulation, concentrations of total chlorophyll in fresh leaves, seed yield and seed protein of geeengram inoculated with Bradyrhizobium sp. (vign) in sandy clay loam

\begin{tabular}{|c|c|c|c|c|c|c|c|c|c|}
\hline \multirow[t]{2}{*}{ Herbicides } & \multirow{2}{*}{$\begin{array}{l}\text { Dose } \\
\text { rate } \\
\left(\mu \mathrm{gkg}^{-1}\right)\end{array}$} & \multicolumn{2}{|c|}{ Mean Length (cm) } & \multirow{2}{*}{$\begin{array}{l}\text { Mean plant } \\
\text { dry weight } \\
\left(\mathrm{g} \text { plant }^{-1}\right)\end{array}$} & \multicolumn{2}{|c|}{ Nodules } & \multirow{2}{*}{$\begin{array}{l}\text { Mean total } \\
\text { chlorophyll } \\
\left(\mathrm{mg} \mathrm{g}^{-1}\right)\end{array}$} & \multirow{2}{*}{$\begin{array}{l}\begin{array}{l}\text { Mean seed } \\
\text { yield } \\
\left.\text { plant }^{-1}\right)\end{array}\end{array}$} & \multirow{2}{*}{$\begin{array}{l}\text { Mean seed } \\
\text { protein } \\
\left(\mathrm{mg} \mathrm{g}^{-1}\right)\end{array}$} \\
\hline & & Root & Shoot & & $\begin{array}{l}\text { Mean } \\
\text { No. plant }\end{array}$ & $\begin{array}{l}\text { Mean dry } \\
\text { weight (mg } \\
\left.\text { plant }^{-1}\right)\end{array}$ & & & \\
\hline \multirow[t]{2}{*}{ Atrazine } & 200 & $19 \mathrm{bc}$ & $18^{*} \mathrm{fh}$ & $2.6 *$ be & $5 *$ bce & $60 *$ bec & $0.8 \mathrm{eh}$ & $150 * \mathrm{c}$ & $170 \mathrm{cfg}$ \\
\hline & 400 & $17 * \mathrm{ch}$ & $20 \mathrm{~h}$ & $2.5^{*} \mathrm{e}$ & $3 * \operatorname{cdef}$ & $40 *$ cde & $0.2 * \mathrm{df}$ & $120 * \mathrm{~d}$ & $125 * \mathrm{~d}$ \\
\hline \multirow[t]{2}{*}{ Isoproturon } & 200 & 19 & $22 \mathrm{~d}$ & $3.0 \mathrm{dh}$ & $4 * \operatorname{def}$ & $50 *$ de & $1.1^{*} \mathrm{gh}$ & $170^{*}$ & $165 \mathrm{gh}$ \\
\hline & 400 & $14^{*}$ efh & 21 & $2.9 \mathrm{~h}$ & $2 *$ ef & $30 *$ ef & $0.4 * \mathrm{e}$ & $110^{*}$ & $124^{*}$ \\
\hline \multirow[t]{2}{*}{ Metribuzin } & 200 & $14^{*} \mathrm{fh}$ & $24 * \mathrm{~g}$ & $2.4^{*}$ & $3 * \mathrm{f}$ & $40 * \mathrm{f}$ & 0.6 & - & - \\
\hline & 400 & $13^{*} \mathrm{~h}$ & $18^{*} \mathrm{~h}$ & $2.1^{*}$ & $2 *$ & $20^{*}$ & $0.1^{*}$ & - & - \\
\hline \multirow[t]{2}{*}{ Sulfosulfuron } & 200 & $23 *$ & $24^{*}$ & 3.2 & 12 & $150 \mathrm{~h}$ & $1.2 *$ & $220 \mathrm{~h}$ & $178 \mathrm{~h}$ \\
\hline & 400 & $15 *$ & $19^{*}$ & 2.9 & $19^{*}$ & 145 & 0.9 & 210 & 182 \\
\hline Control & & 20 & 21 & 3.0 & 10 & 140 & 0.8 & 200 & 175 \\
\hline LSD & & 2.0 & 1.5 & 0.2 & 2.8 & 20 & 0.2 & 20 & 17.5 \\
\hline
\end{tabular}

letter are not significantly different from each other at $5 \%$ level of probability according to Duncan ${ }^{\text {ss }}$ multiple range test.

There are several possible mechanisms by which the $\mathrm{N}_{2}$ fixing bacteria can influence the growth of their host plants. The mechanisms include: degradation/mineralization of herbicides by which it reduces the toxic effects of herbicides to the plants and production of phytohormones. The plant growth promoting characteristics such as the production of IAA was further investigated in this study. The Bradyrhizobium strain BR-9 grown in LB broth supplemented with 50, 75 and $100 \mu \mathrm{g} \mathrm{ml}^{-1}$ of tryptophan exhibited a substantial production of IAA. The data revealed a concentration dependent increase in IAA with a maximum of $146 \mu \mathrm{g} \mathrm{ml}^{-1}$ in LB broth having $75 \mu \mathrm{g} \mathrm{ml}^{-1}$ of tryptophan. In comparison, 100 $\mu \mathrm{g} \mathrm{m}{ }^{-1}$ of tryptophan yielded comparatively poor amount of IAA (Fig.2). Similar trends were also observed with other bacterial isolates (Frah et al., 2005). Considering such potentials, herbicidal toxicity was tested for greengram plants in a pot soil experiment. When greengram was grown in sandy clay loam soils amended with 200 and $400 \mu$ g.a.i. $\mathrm{kg}^{-1}$ of atrazine, isoproturon, metribuzin and sulfosulfuron, had a variable effect on plant growth (Table 1). Metribuzin at $200 \mu$ g.a.i. $\mathrm{kg}^{-1}$ significantly $(\mathrm{P} \leq 0.05)$ reduced the length of root while sulfosulfuron at the same rate significantly enhanced the root length compared to control. Metribuzin and sulfosulfuron, however, significantly enhanced the shoot length, while atrazine declined the shoot length at 200 $\mu$ g.a.i. $\mathrm{kg}^{-1}$. Generally, the effect on the plant parts was more severe at $400 \mu$ g.a.i. $\mathrm{kg}^{-1}$ for each herbicide.

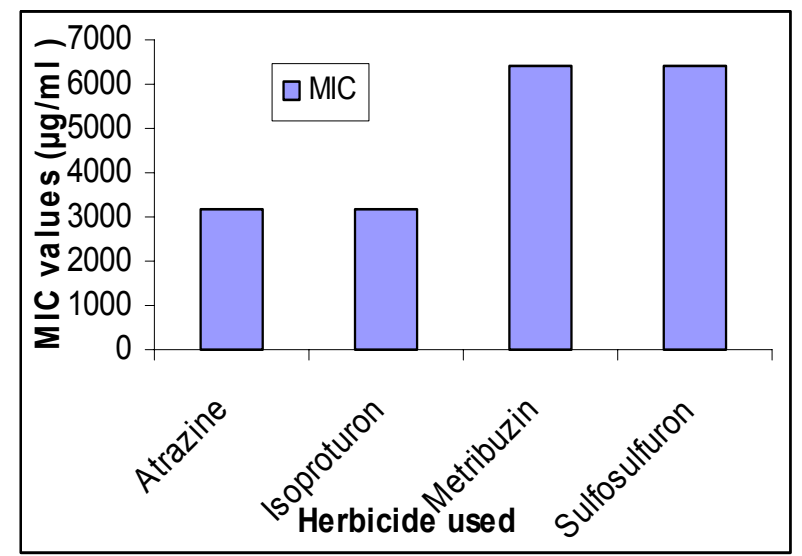

Fig: 1 Evaluation of atrazine, isoproturon, metribuzin and sulfosulfuron for their toxicity to Bradyrhizobium sp. (vigna) BR9 on YEM agar plates

The average maximum reduction in root length $(35 \%)$ and shoot length (14\%) occurred at $400 \mu$ g.a.i.kg ${ }^{-1}$ of metribuzin relative to the control. Atrazine and metribuzin at the tested dose rates significantly decreased the whole dry weight of plants compared to the control. In comparison, isoproturon and sulfosulfuron at the same rates either stimulated or showed no significant adverse effect on dry matter accumulation in greengram plants relative to the control. Among the herbicides, metribuzin at 200 and $400 \mu$ g.a.i. $\mathrm{kg}^{-1}$ showed a greater phytotoxic effect and reduced the total dry matter production by 20 and $30 \%$, respectively, as compared with the control. While comparing the sum of mean values of two dose rates of each herbicide independently, the order of toxicity on total biomass production increased in the 
following order: sulfosulfuron $<$ isoproturon $<$ atrazine $<$ metribuzin. Evaluation of the herbicide effects on legume cultivation is complicated because herbicide may not only affect the rhizobia in the free living state in soil and within root tissues but also affect plant growth (Singh and Wright, 2002). In the present study, the trend observed, suggests that the lower rate $\left(200 \mu\right.$ g.a.i. $\left.\mathrm{kg}^{-1}\right)$ in general, had little effect on the growth of the test plants suggesting that herbicides at this rate persisted in soil for only a short duration, after which the viable cells of Bradyrhizobium recovered and multiplied rapidly leading thereby to the establishment of an effective symbiosis with the host plant. This seems possible because the soil environment can act as a buffer, which can reduce the toxic effect of herbicides through dilution. Further, the isoproturon and sulfosulfuron enhanced the dry matter accumulation in greengram plants possibly due to their rapid mineralization in the soil (Sorensen and Aamand, 2003) or due to the availability of IAA by the organism, for the growing plants. In comparison, the higher concentrations (400 $\mu$ g.a.i. $\left.\mathrm{kg}^{-1}\right)$ of the herbicides used, reduced the dry matter accumulation in the test crop possibly due to disruption of certain metabolic pathways, e.g., aromatic amino acid biosynthesis (sulfosulfuron) or photosynthesis (metribuzin and atrazine). Sulfosulfuron, a selective herbicide cause plant death by inhibiting aceto lactate synthase (ALS), the enzyme involved in the biosynthesis of amino acids. During the Rhizobiumlegume interaction, the legume host provides Rhizobium the energy required for $\mathrm{N}$ fixation where as the ALS regulates the synthesis of aromatic amino acids (AAA). Presumably, the inhibition of AAA synthesis eventually leads to depletion of protein and therefore, lack of some essential protein function eventually leads to decreased plant growth. Similar inhibition of ALS with sulfonyl urea herbicide is reported (Ray, 1985). Among the four herbicides, atrazine and metribuzin showed a strong negative impact on vigour of inoculated greengram plant.

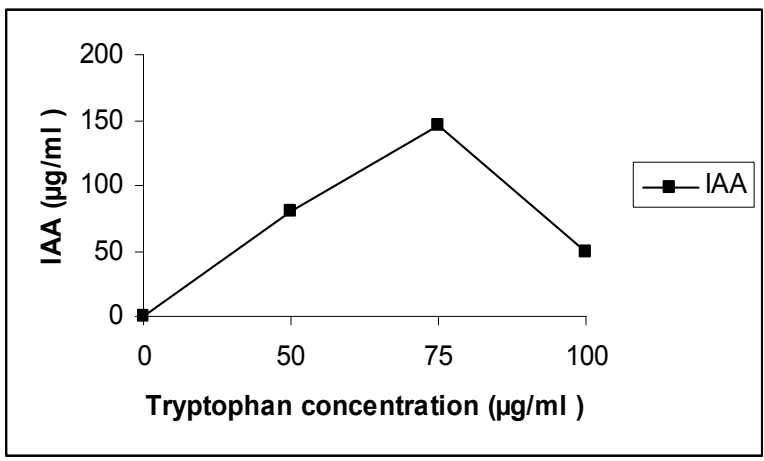

Fig 2: Production of IAA by Bradyrhizobium sp. (vigna) BR9 in LB broth amended with different concentration of tryptophan
The effect of two doses of the herbicides on the nodulation of greengram plants was variable (Table $1)$. Generally, the number of nodules formed on the root system of greengram plant decreased at 200 and $400 \mu$ g.a.i. $\mathrm{kg}^{-1}$ of atrazine, isoproturon and metribuzin. In contrast, sulfosulfuron at 200 and 400 $\mu$ g.a.i. $\mathrm{kg}^{-1}$ enhanced the number of nodules by 20 and $90 \%$, respectively, compared to the control. The decrease in number of nodule ranged between 50 (at $200 \mu$ g.a.i. $\mathrm{kg}^{-1}$ of atrazine) to $80 \%$ (at $400 \mu$ g.a.i. $\mathrm{kg}^{-1}$ each of isoproturon and metribuzin).In comparison, sulfosulfuron at both rates, significantly increased the number of nodules compared to those observed for atrazine, isoproturon and metribuzin. A trend similar to the number of nodules was followed for each herbicide and their dose rates with nodule dry mass. The lack of inhibitory effect on nodulation observed with sulfosulfuron could be due to its rapid inactivation in soils or its rapid translocation along with photosynthate, to distant metabolic sink. However, the herbicide induced decline in nodulation, could be due to the inhibition of symbiosis between the greengram and the Bradyrhizobium or due to a strong decrease in nitrogenase activity which led to nodule senescence (Fernandez Pascual at al., 1992).

The effect of herbicide treatments on chlorophyll content in foliage at flowering (45 DAS) consistently declined with increasing rates of herbicides but was significant $(\mathrm{P} \leq 0.05)$ only at $400 \mu$ g.a.i.kg ${ }^{-1}$ of atrazine, isoproturon and metribuzin. In contrast, 200 $\mu \mathrm{g}$ a.i. $\mathrm{kg}^{-1}$ of isoproturon and sulfosulfuron stimulated the chlorophyll content in fresh leaves of greengram. The reduction in photosynthetic pigments could be due to inhibition in photosynthesis. For instance, metribuzin inhibits photosynthesis by blocking electron transfer from compound Q to plastoquinone in photosystem II (Fedtke, 1982) and hence prevent the reduction of $\mathrm{NADP}^{+}$required for $\mathrm{CO}_{2}$ fixation. Further, the pigment deficiency in the foliage of greengram plants may be caused by photobleaching (Barry et al., 1990). Moreover, the decreased supply of photosynthate to the roots due to totoxic action of atrazine and metribuzin and the direct effects of these herbicides on the growth of Bradyrhizobium in vitro might have resulted in the reduction of functional symbiosis. The data from this study thus supported the concept that the detrimental effect of atrazine and metribuzin is primarily bacterium mediated that resulted in the indirect effects on nodulation and yield (Alonge, 2000).

Seed yield increased marginally with 200 and 400 $\mu$ g.a.i. $\mathrm{kg}^{-1}$ of sulfosulfuron while atrazine and isoproturon, at the same rates significantly $(\mathrm{P} \leq 0.05)$ declined the seed yield compared to control. The decrease in seed yield ranged between 15 (200 $\mu$ g.a.i. $\mathrm{kg}^{-1}$ of isoproturon) to $45 \%$ (400 $\mu$ g.a.i. $\mathrm{kg}^{-1}$ of 
isoproturon). Sulfosulfuron at 200 and $400 \mu$ g.a.i.kg

${ }^{1}$ increased the seed yield by 47 and $75 \%$ compared to the same rates of atrazine and by 29 and $91 \%$ compared to the isoproturon. Metribuzin however, completely inhibited the seed production both at 200 and $400 \mu$ g.a.i. $\mathrm{kg}^{-1}$ of soil. In the present study, sulfosulfuron did not adversely affect seed production probably due to the $\mathrm{N}$ acquisition by the plants via $\mathrm{N}_{2}$ fixation or stimulated the plant physiological process, which in turn enhanced the crop yield. In the present study, the adverse effect of herbicides on Bradyrhizobium sp. (vigna) in pure culture was observed at concentrations not normally expected to occur under field conditions. The observed adverse effects of these herbicides on nodulation and yield of greengram was possibly, not due to their effects on Bradyrhizobium sp. (vigna) but to their effect on the plant growth itself. Further, no correlation occurred between the effect of herbicides on this bacterium in vitro and the Bradyrhizobium-greengram symbiosis under pot trials. The discrepancies in the results may be in part due to the variations in the experimental procedures. The maximum reduction in grain protein (GP) was observed at $400 \mu$ g.a.i. $\mathrm{kg}^{-1}$ of isoproturon (124 mg g ${ }^{-1}$ of seed) and atrazin (125 mg g ${ }^{-1}$ of seed) compared to the control. In contrast, sulfosulfuron at $400 \mu$ g.a.i. $\mathrm{kg}^{-1}$ marginally increased the GP relative to control. Sulfosulfuron at $200 \mu$ g.a.i. $\mathrm{kg}^{-1}$ showed an increase of 5 and $8 \%$ over $200 \mu$ g.a.i. $\mathrm{kg}^{-1}$ of atrazin and isoproturon, respectively, while at $400 \mu$ g.a.i. $\mathrm{kg}^{-1}$ enhanced the GP by 46 and $47 \%$ compared to those obtained for atrazine and isoproturon. While comparing the sum of the mean values of two rates and each herbicide, the order of toxicity on GP of inoculated greengram increased in the following order: sulfosulfuron $<$ atrazine $<$ isoproturon $<$ metribuzin. Direct effects of herbicides on protein or nucleic acid synthesis have not yet been discovered, probably because neither of these sites are primary sites of action of any commercial herbicide. However, in the present study, the protein content in grains of greengram was found to be severely affected by the highest dose rates of atrazine and isoproturon, suggesting that the enzymes and other functional proteins are one of the target sites of herbicide toxicity, which subsequently leads to alteration in the protein metabolism of grains. This work exemplifies the inhibitory effect of atrazine and metribuzin on nodule bacterium and inoculated greengram, resulting in a substantial decline in both the quantity and quality of greengram seeds. The application of atrazine and metribuzin to control weeds in greengram cultivation system should strongly be avoided.

\section{REFERENCES}

Alonge, S O (2000). Effect of imazaquin applications on the growth, leaf chlorophyll and yield of soybean in the guinea savanna of Nigeria. J Env Sci Health Part B 35: 321-336.

Barry, P; Young, A J; Briton, G (1990). Photodestruction in higher plants by herbicide action. J Exp Bot 41: 123-126.

Billore, S D; Joshi, O P; Ramesh, A (2001). Effect of herbicides on nodulation, yield and weed control in soybean (Glycine max). Ind J Agric Sci 71: 193-194.

Bollich, P K; Denigan, E P; Kitchen, L M; Burn, R $\mathrm{C}$ (1985). The influence of trifluralin and pendimethalin on nodulation, $\mathrm{N}_{2}\left(\mathrm{C}_{2} \mathrm{H}_{2}\right)$ fixation and seed yield of field grown soybean (Glycine $\max$ L.). Weed Res 36: 15-19.

Bric, J M; Bostock R M Silversone S E (1991). Rapid in situ assay for indole acetic acid production by bacteria immobilized on nitrocellulose membrane. App Environ Microbiol 57: 535-538.

Cork, D J; Krueger, J P (1991). Mirobial transformation of herbicides and pesticides. Adv Appl. Microbiol 36: 1-66.

Durgesha, M (1994). Effect of dinitroaniline herbicides on rhizobia, nodulation and $\mathrm{N}_{2}\left(\mathrm{C}_{2} \mathrm{H}_{2}\right)$ fixation of 4 groundnut cultivars. Ann Appl Biol 124: $75-82$.

Fedtke, C (1982). Biochemistry and physiology of herbicide action, Springer-Verlag, Berlin.

Fernandez Pascual, M; Delerenzo, C; Pozuelo J M; Defelipe M R (1992). Alterations induced by 4 herbicides on lupin nodule cortex structure, protein metabolism and some senescence related enzymes. J Plant Physiol 140: 385-390.

Frah, A; Ahmad, I; Khan, M S (2005). Indole acetic acid production by the indigenous isolates of Azotobacter and fluorescent Pseudomonas in the presence and absence of tryptophan. Turk J Biol 29: 29-34.

Gordon, S; Weber, R P (1951). The calorimetric estimation of IAA. Plant Physiol 26: 192-195.

Heinonen-Tanski, H; Oros, G; Kecskes, M (1982). The effect on soil pesticides on the growth of red clover rhizobia. Acta Agric Scand 32: 283288. 
Holt, J G; Krieg, N R; Sneath, P H A; Staley, J T; Willams, S T(1994). Bergeys Manual of Determinative Bacteriology (Ninth Edition), Williams and Wilkins Pub. Baltimore.

Khan, M S; Zaidi, A; Aamil, M (2004). Influence of herbicides on chickpea Mesorhizobium symbiosis. Agronomie 24: 123-127.

Lowry, O H; Rosebrough, N J; Farr, A L; Randal, R J (1951). Protein measurements with the Folin Phenol reagent. J Biol Chem 193: 265-275.

Mallik, M A B; Tesfai, K (1985). Pesticidal effect on soybean rhizobia symbiosis. Plant Soil 85: 33-41.

Martenson, A M (1992). Effect of agrochemicals and heavy metals on fast growing rhizobia and their symbiosis with small seeded legumes. Soil Biol Biochem 24: 435-445.

Mechenny, G (1941). Absorption of light by chlorophyll solution. J Biol Chem 140: 315-320.

Ray, T B (1985). The site of action of of the sulfonylureas. Proc Brit Crop Protec Conf Weeds. 1: 131-138.
Rennie, R J; Dubetz, S (1984). Effect of fungicides and herbicides on the nodulation and $\mathrm{N}_{2}$ fixation in soybean fields lacking indigenous Rhizobium japonicum. Agron J 76:451-454.

Silva, J C C; Colaco, W; Burity, H.D; Ferreira, N C M; Figuweiredo, M V B; Martinez, C R (1998). Herbicides on nodulation and $\mathrm{N}_{2}$ fixation in cowpea. Pesquisa Agropecuaria Brasileira 33: 77-86.

Singh, G; Wright, D (2002). In vitro studies on the effect of herbicides on the growth of rhizobia. Letters Appl Microbiol 35: 12-16.

Singh, C; Singh, P; Singh, R ( 2004). Modern techniques of raising field crops. India: Oxford and IBH Publishing Company Private Limited. pp. 209-218.

Sorensen, S R; Aamand, J (2003). Rapid mineralization of the herbicide isoproturon in soil from a previously treated Danish agricultural field. Pest Manag Sci 59: 1118-1124 